\title{
THE POSTWAR ORIGINS OF
}

THE GLOBAL ENVIRONMENT 


\section{COLUMBIA STUDIES IN INTERNATIONAL AND GLOBAL HISTORY}

Cemil Aydin, Timothy Nunan, and Dominic Sachsenmaier, Series Editors

This series presents some of the finest and most innovative work coming out of the current landscapes of international and global historical scholarship. Grounded in empirical research, these titles transcend the usual area boundaries and address how history can help us understand contemporary problems, including poverty, inequality, power, political violence, and accountability beyond the nation-state. The series covers processes of flows, exchanges, and entanglements-and moments of blockage, friction, and fracture-not only between "the West" and "the Rest" but also among parts of what has variously been dubbed the "Third World" or the "Global South." Scholarship in international and global history remains indispensable for a better sense of current complex regional and global economic transformations. Such approaches are vital in understanding the making of our present world.

\section{Cemil Aydin, The Politics of Anti-Westernism in Asia: Visions of World Order in Pan-Islamic and Pan-Asian Thought}

Adam M. McKeown, Melancholy Order: Asian Migration and the Globalization of Borders Patrick Manning, The African Diaspora: A History Through Culture James Rodger Fleming, Fixing the Sky: The Checkered History of Weather and Climate Control

Steven Bryan, The Gold Standard at the Turn of the Twentieth Century: Rising Powers, Global Money, and the Age of Empire

Heonik Kwon, The Other Cold War

Samuel Moyn and Andrew Sartori, eds., Global Intellectual History

Alison Bashford, Global Population: History, Geopolitics, and Life on Earth Adam Clulow, The Company and the Shogun: The Dutch Encounter with Tokugawa Japan Richard W. Bulliet, The Wheel: Inventions and Reinventions Simone M. Müller, Wiring the World: The Social and Cultural Creation of Global Telegraph Networks

Will Hanley, Identifying with Nationality: Europeans, Ottomans, and Egyptians in Alexandria

Perin E. Gürel, The Limits of Westernization: A Cultural History of America in Turkey

Dominic Sachsenmaier, Global Entanglements of a Man Who Never Traveled: A Seventeenth-Century Chinese Christian and His Conflicted Worlds 


\title{
THE POSTWAR ORIGINS OF THE GLOBAL ENVIRONMENT
}

\author{
HOW THE UNITED NATIONS \\ BUILT SPACESHIP EARTH
}

PERRIN SELCER

Columbia University Press

New York 


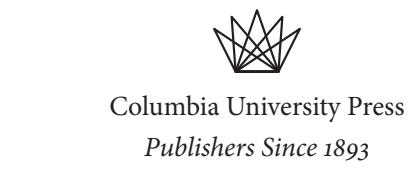

New York Chichester, West Sussex

cup.columbia.edu

Copyright (C) 2018 Columbia University Press

All rights reserved

\section{Library of Congress Cataloging-in-Publication Data}

Names: Selcer, Perrin, author.

Title: The postwar origins of the global environment : how the United Nations built Spaceship Earth / Perrin Selcer.

Description: New York : Columbia University Press, 2018. | Series: Columbia studies in international and global history | Includes bibliographical references and index.

Identifiers: LCCN 2018009049 (print) | LCCN 2018027032 (ebook) | ISBN 9780231548236 (e-book) | ISBN 9780231166485 (cloth : alk. paper) Subjects: LCSH: Environmentalism-International cooperation-History2oth century. | Environmental policy-International cooperation-History2oth century. | Science-International cooperation-History-2oth century. | Internationalism-History—2oth century. | World politics-1945-1989. |

United Nations-History.

Classification: LCC GE195 (ebook) | LCC GE195 .S385 2018 (print) |

$\mathrm{DDC}_{363.7 / 0526-\mathrm{dc} 23}$

LC record available at https://lccn.loc.gov/2018009049

Columbia University Press books are printed on permanent and durable acid-free paper.

Printed in the United States of America

Cover design: Noah Arlow 
TO ALEXANDRA KULKA-WELLS (1973-2012), A NATURAL-BORN WORLD CITIZEN.

I MISS YOU EVERY DAY. 
